\title{
Role of Power in Supply Chain Performance: Evidence from Agribusiness SMEs in Uganda
}

\begin{tabular}{|r|l|}
\hline Journal: & Journal of Agribusiness in Developing and Emerging Economies \\
\hline Manuscript ID & JADEE-09-2016-0066.R1 \\
\hline Manuscript Type: & Research Paper \\
\hline Keywords: & $\begin{array}{l}\text { power, triad, structural Equations modeling, agribusiness SMEs, Supply } \\
\text { chain performance }\end{array}$ \\
\hline \multicolumn{2}{|l}{} \\
\hline
\end{tabular}

\section{SCHOLARONE ${ }^{m}$ \\ Manuscripts}




\title{
Role of Power in Supply Chain Performance: Evidence from Agribusiness SMEs in Uganda
}

\begin{abstract}
Purpose: This paper examined the role of power on supply chain performance in the context of small and medium sized agribusiness enterprises (SMEs). Contrary to most of previous studies, which collect and analyze data from one side of a relationship dyad using a focal firm approach, a matched triad approach was employed in data collection and analysis in this study.
\end{abstract}

Methodology: Empirical data was collected from 150 agribusiness supply chain members from the maize supply chain in Uganda. Analysis was done using multi-group analysis and structural equations modelling.

Findings: Results highlights the differences in the perception of power use and how it influences supply chain performance. The differences in perception suggest the existence of power asymmetry amongst supply chain members. This work contributes to the ongoing debate concerning the use of triad as a unit of analysis as opposed to a firm or a dyad.

Limitations: This study only focused on one commodity chain in one country, which can limit the broad application of the findings.

Managerial implications: A practical implication of the finding is that managers of agribusiness supply chains should be aware of their power positions and appropriately influence the supply chain based on their relative power positions.

Originality: The novelty of this work lies in fact that we assess perception of power amongst supply chain members in a triadic context, a perspective that has not been adequately tested in agribusiness supply chain management studies before.

Keywords: Power, Triad, Structural Equations Modelling, Agribusiness SMEs, Supply chain performance

Type: Research Paper

\subsection{Introduction}

The role of power in supply chains presumes a disproportionate distribution of power amongst supply chain members owing to variations in cost structure, size of the organization capability and nature of contracts (Belaya et al., 2009; He et al., 2013; Cuevas et al., 2015; Lacoste and 
1 Blois, 2015; Rindt and Mouzas, 2015). This implies that supply chain members are

2 interdependent in a complex supply chain structure (Cai et al., 2013; Chicksand, 2015;

3 Odongo et al., 2016). Supply chain management (SCM) literature demonstrates that power is

4 a vital predictor of supply chain performance (SCP) (Molnár et al., 2010; Nyaga et al., 2013),

5 adoption (Liu et al., 2015), innovation capacity (Kühne et al., 2013), and customer

6 integration (Zhao et al., 2008).

7

However, the role of power relations in supply chains is evolving as firms become more complex and multifaceted. Therefore it is important to understand how power is being used by different supply chain members in order to gain control and share profit and ultimately how it affect the supply chain performances (Nyaga et al., 2013; Rindt and Mouzas, 2015). Especially in the context of small and medium sized enterprises (SMEs), power disparity affect firms collaborative behaviors, either due to opportunism or stronger members taking advantage to appropriate greater value of the relationship (Martin K Hingley, 2005; Nyaga et al., 2013; Lackes et al., 2015). Hence this study seek to investigate the negative and positive effects of power on supply chain performance and how supply chain use and perceive power (SCM) (Belaya et al., 2009; Liu et al., 2015).

Furthermore, there is a limited research on role of power in SCP in the context of SMEs (Adams et al., 2012; Sukwadi et al., 2013). Large organizations are often well equipped and prepared to play the power games in their favor. It is important for the managers in small and medium sized businesses to get a better understanding of the role of power and how to deal with it (Gelinas and Bigras, 2004; Matanda et al., 2016). Additionally, this research has a significant managerial implication in agribusiness sector give that in developing countries such as Uganda are primarily dominated by small businesses (Matanda et al., 2016). 
In departure from previous studies, this paper makes three additional contributions to

2 the SCM literature. Firstly, past studies on power in supply chains have focused on its influence on resource allocation (Pulles et al., 2014); power asymmetry (Nyaga et al., 2013); commitment (Zhao et al., 2008); relationship strength (Maloni and Benton, 2000); and performance (Crook and Combs, 2007; Molnár et al., 2010). With a few exceptions such as Molnár et al. (2010) and Kühne et al. (2013), the majority of these studies collect and analyze data from one side of a relationship dyad using a focal firm approach. Analyzing a supply chain at firm or dyadic levels limits understanding the underlying dynamics of the entire supply chain relationships (Molnár et al., 2010; Wu et al., 2010; Kühne et al., 2013; Touboulic et al., 2014). Consequently, there is a need to look beyond the dyad and into the triad as a unit of analysis.

Secondly, relationships are by nature bi-directional, as such, there will be differences in perceptions and expectations amongst supply members (Molnár et al., 2010; Wu et al., 2010; Nyaga et al., 2013; Pulles et al., 2014; Odongo et al., 2016). Positive outcomes for the whole supply chain will contribute to an individual member's success (Medlin, 2006; Gagalyuk et al., 2013; Petrick et al., 2016). Consequently, focusing on one side of a relationship dyad limits our assessment and understanding of perceptual congruence amongst supply chain members (Erin Anderson and Weitz, 1992; Mentzer et al., 2001; Rungtusanatham et al., 2003). As such, focusing on the triad as a unit of analysis will facilitate our understanding of how supply chain members perceive power use and its influence on performance (Minna Rollins and Schreiner, 2015).

Thirdly, by focusing on agribusiness SMEs in a developing country, this paper departs from most previous studies that focused on large enterprises in developed countries (Sukwadi et al., 2013). Agribusiness SMEs participate in several interlinked supply chains which make 
1 supply chain relationships a critical issues for their success (Park and Krishnan, 2001; Adams

2 et al., 2012; Sukwadi et al., 2013).

3 Using a triadic approach, this paper examined the perception of power use and its 4 influence on SCP amongst agribusiness SMEs in a developing country context. We 5 hypothesize that the perception of power use and its effects on SCP may not be shared across 6 a relationship triad. The subsequent section presents theoretical perspective and hypothesis 7 guiding the study followed by the methodology, results, discussion and conclusions as well as 8 recommendations drawn from the study.

9

\section{Conceptual framework and hypotheses}

This paper uses triadic data collection and analysis to examine a triadic business relationship. Using a triadic approach is appropriate because it enables access to detailed data than would be got using focal firm approach (Minna Rollins and Schreiner, 2015). To facilitate understanding of this triadic power relationships, this study is grounded on the Resource Dependence Theory (RDT). The RDT propagates that firms depend on each other because it is not feasible to be self-sufficient and cost effective (Pfeffer and Salancik, 1978; Belaya and Hanf, 2011; Wynstra et al., 2015). Hence, businesses collaborate to the use each other's resources and enter into a business relationship (Cai et al., 2013; Murthy and Paul, 2016). Furthermore, the extent to which a member is dependent on another member depends on two important factors, i.e., uniqueness of the resource, monopoly over it. Therefore managers in small businesses have to make best possible use of resources, thereof power to operate optimally (Pfeffer and Salancik, 1978). Moreover, perception of supply chain members differs regarding use of power and its influence on SCP (Besser and Miller, 2010). The RDT is therefore relevant in this study and has been used in previous studies to assess power relationships in supply chains (Fynes et al., 2005; Adams et al., 2012; Sanfiel-Fumero et al., 2012; Cai et al., 2013; Chicksand, 2015; Liu et al., 2015). The application of the RDT 
1 in this study is therefore relevant and important in advancing the conceptual and practical

2 understanding of the role of power in influencing SCP in triadic agribusiness SMEs.

3

\section{$4 \quad 2.1$ Supply chain performance (SCP)}

5 We define SCP as the operational measures that improve for each member, as well as for the 6 whole chain as result of participation in a supply chain relationship (Arzu Akyuz and Erman 7 Erkan, 2010; Molnár et al., 2010; Whipple et al., 2010; Gagalyuk et al., 2013). Previous 8 studies have established that collaborative relationships are associated with improved SCP in 9 terms of cost reduction, increased fill rate, reduced inventory, and improved quality (Molnár et al., 2010; Nyaga et al., 2010; Thomas et al., 2011). Further, the supply chain members requires a positive evaluation of the performance outcomes of a relationship in order to justify continued involvement in collaborative activities (Wang et al. (2010).

Even though collaborative behaviors result in mutual gains, it is important to stress here that these potential gains may not be equally shared among supply chain members. Previous studies provide evidence of perceptual differences amongst supply chain members with regard to the nature of relationships and SCP (Molnár et al., 2010; Whipple et al., 2010; Kühne et al., 2013; Nyaga et al., 2013). (Erin Anderson and Weitz, 1992) showed that perceptual differences can negatively affect the relationships among chain members and results dissatisfaction and conflict. Similarly, while buyers and suppliers both benefited from collaborations, suppliers had a greater feeling of inequality (Corsten and Kumar (2005). Moreover, supply chain members are likely to possess different sources of power, which can be used to create a certain level of stability or deterrence (Nyaga et al., 2013).

This study pre-supposes that suppliers, focal firms and customers differ in their perception of power and its effect on SCP. SCP is measured in terms of efficiency, responsiveness, quality and chain balance. Efficiency is the best use of available resources 
1 which include measures such as logistic costs and profits (Neely et al., 1995; Aramyan et al.,

2 2007). Logistic cost refers to the operating and opportunity cost items that can be influenced

3 by logistic decisions and the integration of management practices and activities throughout

4 the supply chain. Profits are the net positive gains from an investment. Responsiveness is the

5 measure of speed/rate of providing the requested products, hence we considered lead-time and

6 customer complaints (Aramyan et al., 2007; Molnár et al., 2010; Sukwadi et al., 2013). Lead

7 time is the total amount of time which elapses between sending/getting and

8 delivering/receiving goods or services (Gunasekaran et al., 2001). Customer complaint is

9 defined as the formal complaints from customers regarding the product. Product quality

10 means safety and attractiveness while process quality is measured by environmental

11 friendliness (Neely et al., 1995; Chen and Paulraj, 2004; Aramyan et al., 2007). Chain

12 balance is defined as the understanding of distribution of risks and benefits. Risks and benefits

13 distribution refers to the extent to which business risks and compensations are shared amongst

14 supply chain members. Finally, supply chain understanding refers to chain members'

15 understanding of each other's products and processes (Molnár et al., 2010).

16

17

18

19

20

21

\subsection{Influence of power on supply chain performance}

Power has been recognized as an important antecedent of SCP (Geyskens et al., 1999). Power

is the supply chain member's ability to influence the perception, conduct and/or decisions of another (Jonsson and Zineldin, 2003). Research indicates that there is always a power imbalance amongst supply chain members due to the existences of large enterprises with greater power than small ones (Cai et al., 2013; Li et al., 2013; Martin Hingley et al., 2015). Power imbalances usually arise due to differences in expertise, size, dependence, and the nature of contract (Martin K Hingley, 2005; Belaya et al., 2009; Gellynck and Molnár, 2009;

Kühne et al., 2013; Li et al., 2013; Jones et al., 2014). 

In the context of agribusiness SMEs in Uganda, processors and wholesalers usually

2 3

\section{The context of agribusiness SMEs in Uganda, processors and wholesalers usually}

have more resources (capital) and better access to market information as compared to their suppliers and customers. This unequal access to resources and information implies that focal firms have a final say on purchasing decisions such as price, quantity, quality amongst others. Consequently, there is more power in with the focal firms (processors and wholesalers) compared to the suppliers and customers. These powerful supply chain members might assume a greater influence and create some stability along the supply chain. Alternatively, powerful supply chain members may use their power advantage at the cost of the weaker members (Belaya et al., 2009; Nyaga et al., 2013; Cuevas et al., 2015; Rindt and Mouzas, 2015). Due to their weak position in the supply chain, the weaker members are most likely to comply with the stronger members for fear of losing business. It is therefore important to understand the nature and effects of power in supply chains in order to provide balanced benefit distributions for all supply chain members (Nyaga et al., 2013).

Power bases examines the potential reasons why one member may hold authority over another. According to French et al. (1959), power bases include: coercive and non-coercive which indicate the ability of the power holder to mediate punishments or dividends; expert power which is the perception that one member holds information or expertise which is valued by another; referent power, which is one member's desire for identification with another for recognition by association; and legitimate power where one member believes in the right of the other member to wield influence. Of these power bases, the coercive and noncoercive dichotomy is the most apparent and widely recognized power bases (Maloni and Benton, 2000; Bastl et al., 2013).

Using the coercive/non-coercive dichotomy, we view power as a mechanism by which one supply chain member induces a desired action of another supply chain member by providing/withholding rewards or punishment. Coercive power occurs when a member's 
1 power permits it to affect another member's share of the benefits of a supply chain

2 relationship. It represents a power struggle driven by force by one supply chain member over 3 another (Skinner et al., 1992). This power struggle may reduce the level of cooperation and 4 performance; and increase the level of conflict and tension in a supply chain relationship 5 hence reduced SCP (Terpend and Ashenbaum, 2012). Past studies has shown that coercive 6 power negatively influences SCP. We therefore hypothesize that:

\section{$7 \quad H 1_{a}: \quad$ Coercive power negatively affects efficiency}

$8 \quad H 1_{b}:$ Coercive power negatively affects quality

$9 \quad H 1_{c}:$ Coercive power negatively affects responsiveness

$\boldsymbol{H 1}_{d}$ : Coercive power negatively affects chain balance

11

Non-coercive power is based on rewards and the belief that another member is able to administer positive rewards and minimize negative rewards (French et al., 1959). Noncoercive power therefore involves rewards and assistances and increases the value of a relationship through team support, common interests and supporting collective goals (Jonsson and Zineldin, 2003). Previous studies have postulated that non-coercive power has a positive effect on SCP (Zhao et al., 2008; Nyaga et al., 2013), hence, we hypothesize that:

H2a: Non-coercive power positively affects efficiency

$\boldsymbol{H} 2_{b}: \quad$ Non-coercive power positively affects quality

H2c: Non-coercive power positively affects responsiveness

H2d: Non-coercive power positively affects chain balance

The conceptual framework underpinning the stated hypotheses is presented in figure 1.

\section{Insert figure 1}

\section{Methods}




\subsection{The maize supply chain in Uganda}

2 Data for this study was collected from SMEs in the maize supply chain in Uganda. The maize 3 industry is selected for this study because maize is Uganda's most important non-traditional 4 exports and food security commodity. Maize sector provides a source of livelihood to over 3 5 million households in Ugandan (MFPED, 2016). Much of the maize produced in Uganda is 6 sold to regional markets, especially in Kenya, South Sudan, Malawi, Zambia, and Zimbabwe, 7 (Ahmed, 2012).

\subsection{Data collection}

Primary data was collected between April 2014 and February 2015. We employed face to face interviews with managers of agribusiness SMEs. A matched triad approach (Kühne et al., 2015) was used in data collection. Using a matched triad approach helped to minimize the chances of sampling bias (Rungtusanatham et al., 2003; Wuyts et al., 2004; Boyer and Swink, 2008). Additionally, the choice of a matched triad approach was done so as to facilitate the subsequent triadic data analysis.

Therefore, each supply chain considered had a triplet of supply chain members (supplier, focal firm, and customer). Data collection always started with the focal firms (FF), 
1 which were purposively identified based on their involvement in the maize supply chain as

2 either a processor or wholesaler. This facilitated the subsequent snowball identification of the 3 supplier (S) and customer (C) by the FF. Each FF was first asked to identify one of their

4 important supplier (S) and customer (C) before being asked to indicate their subjective

5 assessment with respect to their individually chosen supplier (F_S) and customer (F_C).

6 Similarly, each nominated supplier was requested to provide their subjective assessment with

7 respect to the FF that nominated them (S_F); and each nominated customer was asked to

8 provide their subjective assessment with respect to the FF that nominated them (C_F). To be

9 considered for inclusion, suppliers had to be dealing directly in maize or maize products.

10 Therefore, nominated suppliers who were dealing in services such as transportation or other

11 inputs were left out of the interview process. For customers, the inclusion criteria was that

12 they had to be buying maize or maize product directly from the FF that nominated them. In

13 case of a non-response or a mismatch from one of the nominated $\mathrm{C}$ of $\mathrm{S}$, the whole supply

14 chain was dropped from the interview process. These perspectives of data collection are 15 summarized in figure 2.

\section{Insert figure 2}

The snowball sampling technique was deemed ideal for the study as little was known about the underlying dimensions of the study population. As such, the ex-ante identification of respondents was not feasible (Molnár et al., 2010). At the end, realized 50 matched triads (150 successful interviews), that is $90 \%$ completion rate for the initiated interviews, which is consistent with the snowball method of sampling. The 50 maize supply chains comprised 50 suppliers, 50 focal firms, and 50 customers. Most (73\%) of the responding firms were small enterprises, who had been in business operations for more than five years. The majority (59\%) was involved in the marketing of maize as flour. The firms were involved in the production, processing and marketing of maize in form of flour, feeds, seeds and grains (Table 1). 


\section{Insert Table 1}

2

\section{$3 \quad 3.3$ Measurements and scaling}

4 We adapted the survey measurement items based on similar past studies conducted on power 5 (Kühne et al., 2013), and SCP (Molnár et al., 2010; Wu et al., 2010; Kühne et al., 2013) (see

6 table 2 for statements used). The first section of the questionnaire assessed the supply chain

7 members' characteristics. The second section examined the perception of power use amongst 8 supply chain members, making use of four statements, representing coercive power and non9 coercive power sources. The third section assessed perception of SCP, using 11 statements belonging to the four SCP constructs. All items were measured on a 5-point Likert scale (1strongly disagree, 2-disagree, 3-neutral, 4-agree, 5-strongly agree).

\subsection{Analysis}

Data was analyzed in SPSS version 21 and AMOS 22. Since the constructs were being used in Uganda for the first time, we conducted an exploratory factor analysis (EFA) to assess the uni-dimensionality of the scales (Narasimhan and Jayaram, 1998; Zhao et al., 2008). The EFA with principal component analysis (PCA) was done without specifying the number of factors. Varimax rotation with Kaiser Normalization was used to clarify on the number of factors. Some items were dropped because of cross loadings or low loadings on the respective factors. Cronbach alpha was then calculated for each factor extracted to assess the internal consistency of the extracted components (Janssens et al., 2008). For SCP, four factors with Eigen values greater than one were extracted, explaining $60.17 \%$ of the variations in SCP. The four factors generally maintained the original dimensions in which SCP was measured. For power, two factors explaining $87 \%$ variation in power were extracted (Table 2).

\section{Insert Table 2}


The second stage of analysis involved estimating standardized path estimates so as to

2

3 (SEM). Following James C Anderson and Gerbing (1988), we used a two-step approach of

4 testing a measurement and structural model. A measurement model was built based on the

5 two power and four SCP constructs. The fit indices for the measurement model was good with

$6 X^{2}=94.00, \mathrm{p}$-value $=0.005, \mathrm{GFI}=0.94, \mathrm{CFI}=0.94, \mathrm{RMSEA}=0.05$; which fall within acceptable

7 limits for a CFA ( $\mathrm{Hu}$ and Bentler, 1999; Janssens et al., 2008). We then built a structural

8 model based on the measurement model using the maximum likelihood method. The

9 structural model was modified through co-varying the error terms on efficiency with quality, and quality with responsiveness. The modification resulted in a model with good fit indices $\left(X^{2}=104.04 .54, \mathrm{p}\right.$-value $\left.=0.002, \mathrm{GFI}=0.93, \mathrm{CFI}=0.92, \mathrm{RMSEA}=0.05\right)$, thus explaining clearly the rationale for the acceptability of the model.

\section{Results}

For the pooled sample, results show that coercive power negatively and significantly influenced efficiency, quality and chain balance; hence providing support for hypothesis $\mathrm{H}_{1 \mathrm{a}}$, $\mathrm{H}_{1 \mathrm{~b}}, \mathrm{H}_{1 \mathrm{~d}}$ (Figure 3). This finding is in agreement with previous studies which suggest that coercive power negatively influences SCP (Sanfiel-Fumero et al., 2012; Terpend and Ashenbaum, 2012; Sheu, 2015). Although positive, the influence of non-coercive power on SCP was not significant and hence $\mathrm{H}_{2}$ was not supported.

\section{Insert figure 3}

Multi-group SEM analysis revealed differences in the perceptions of power use and its influences on SCP amongst supply chain members. On the upstream, suppliers perceived the use of coercive power by the FFs to significantly and negatively influence efficiency and chain balance. FFs perceived the use of coercive power by suppliers to positively and significantly influence responsiveness. This outcome is counter intuitive, as literature suggest 
1 that coercive power negatively influences SCP (Sanfiel-Fumero et al., 2012). This result can

2 however be explained by the informal nature of business operations in the maize supply chain

3 in Uganda. In the absences of formal contracts, supply chain members might be forced to use

4 threats, for example loss of contract, to have partners adhere to desired performance standards

5 such as delivery time and quality standards. Looking at non-coercive power, focal firms

6 perceived the use of non-coercive power to positively influence SCP. This results find support

7 in previous studies such as (Sheu, 2015) which suggests that non-coercive power has a

8 positive effect on SCP. The results with respect to the supplier was however not significant,

9 hence inconclusive. Similar studies by (Kühne et al., 2013) in agri-food chains showed indifference on the influence of non-coercive power on SCP.

On the downstream, FF did not consider the use of coercive power by the customer to significantly affect SCP. Customers on the other hand perceived the use of coercive power by the FF to negatively and significantly influence quality and chain balance (Table 3). The perception of customers on the influence of coercive power on SCP finds support in literature from previous studies such as Sanfiel-Fumero et al. (2012) who suggested that coercive power negatively influence SCP. On the other hand, focal firms were indifferent on the influence of non-coercive power on SCP, while customer perceived the use of non-coercive power to negatively influence quality.

\section{Insert Table 3}

Concluding, while our pooled sample results generally provided partial support for $\mathrm{H}_{1}$ $\left(\mathrm{H}_{1 \mathrm{a}}, \mathrm{H}_{1 \mathrm{~b}}, \mathrm{H}_{1 \mathrm{~d}}\right)$, it did not provide support for $\mathrm{H}_{2}$. For the multi-group analysis, we found partial support for both $\mathrm{H}_{1}$ and $\mathrm{H}_{2}$ across the three supply chain members. For $\mathrm{H}_{1}$, there was partial support for $\mathrm{H}_{1 \mathrm{a}}\left(\mathrm{S}_{-} \mathrm{F}\right), \mathrm{H}_{1 \mathrm{~b}}\left(\mathrm{C}_{-} \mathrm{F}\right)$, and counter intuitive support for $\mathrm{H}_{1 \mathrm{c}}\left(\mathrm{F} \_\mathrm{S}\right)$ and $\mathrm{H}_{1 \mathrm{~d}}$ (S_F). For $\mathrm{H}_{2}$, there was no support for $\mathrm{H}_{2 \mathrm{a}}$, while there was partial support for $\mathrm{H}_{2 \mathrm{~b}}\left(\mathrm{C}_{-} \mathrm{F}\right), \mathrm{H}_{2 \mathrm{c}}$ (S_F) and $\mathrm{H}_{2 \mathrm{~d}}\left(\mathrm{~S} \_\mathrm{F}\right)$. The results for the pooled and multi-group analysis support the 
1 assumption that there are perceptual differences amongst supply chain members on the use of 2 power and its influence on SCP.

3

4 5. Discussion

Although most researchers believe that empirical studies on SCP should collect and analyze data from at least three firms in a supply chain (Mentzer et al., 2001; Choi and Wu,

7 2009; Wu et al., 2010), only a few have attempted to do this empirically. This paper provides

8 insights into perception differences amongst supply chain members in a triadic agribusiness

9 SMEs context. The pooled sample results provide partial support $\mathrm{H} 1\left(\mathrm{H}_{1 \mathrm{a}}, \mathrm{H}_{1 \mathrm{~b}}, \mathrm{H}_{1 \mathrm{~d}}\right)$. This is in agreement with previous studies which show that use of coercive power has negative effects on SCP (Sakano and Johnson, 1993; James R Brown et al., 1996; Zhao et al., 2008; Terpend and Ashenbaum, 2012; Nyaga et al., 2013). The results underline the informal environment in which agribusiness SMEs operates in Uganda. Because business relationships are noncontractual and based on trust, exercise of power will only serve to discourage supply chain members from continuing in a business relationship. In practice, if one member perceives that another member is being coercive, it is most likely to retaliate by declining to make specific required adjustments or collaborate in joint relationship activities. The implication is that agribusiness managers need to control their use of coercive power, as it may be counterproductive to their performance in the long run.

The multi-group analysis revealed differences in perception amongst supply chain members on the use of power and its influence SCP. While the perception of suppliers and customers on the use of coercive power is in line with previous studies, there were deviations when it came to the different performance parameters. For suppliers, efficiency and chain balance were significantly influenced by a partners use of coercive power, while for customers, quality and chain balance were critical. For focal firms, the use of coercive power 
1 by the supplier significantly influences responsiveness. This difference in perception reveals

2 that critical SCP parameters vary from one member to another.

3 Contrary to previous studies (Molnár et al., 2010; Terpend and Ashenbaum, 2012),

4 focal firms perceived the use of coercive power to positively influence performance. This

5 could suggest the existence of power asymmetry amongst agribusiness SMEs. This could be

6 the case where there are few suppliers, supplying maize with specific quality requirements to

7 focal firms. Since only few suppliers can meet these quality requirements, suppliers have the

8 power to choose which FF to sell. Hence suppliers can use this power to leverage benefits for 9 themselves.

Focal firms perceived the use of non-coercive power to have significant positive effects on responsiveness and chain balance. This is in agreement with previous studies (James R. Brown et al., 1995; Nyaga et al., 2013), which reported a positive association between non-coercive power and SCP. This suggests that the use of rewards and incentives is a strong signal from a member that they value that relationship. By implication, supply chain members need to consider providing incentives, such as rewards and bonuses to their partners. Such incentives will make partners feel they are appreciated and can result in a positive view of the relationship. Customers perceived non-coercive power to have a significant negative effect on the quality. This result is counter intuitive. However, it finds support from a study by Kühne et al. (2013), who concluded that higher levels of non-coercive power use was associated with low levels of innovation capacity in European traditional food chains.

Comparing the downstream and upstream, our findings suggest that different performance aspects are perceived differently in the two sides of the supply chain. For instance, while responsiveness is an important factor in the upstream, quality is an important factor in the downstream. This actually reflects the actual situation in the maize supply chain in Uganda. In the upstream, there is an need for faster delivery of products so that processing 
1 can be done on time. On the downstream, customers are always demanding for quality

2 product, hence the importance of quality. On the other hand, chain balance appears to be

3 critical in both upstream and downstream. This finding underpins the fact that relationships

4 are bi-directional in nature, as such supply chain members will have differences in

5 perceptions towards business relationships. For agribusiness SME managers, it is essential to

6 understand how their business partners perceive the business relationships. For successful

7 business relationships, focal firms should take effort to understand their relative power

8 positions with respect to both the suppliers and customers (Lacoste and Blois, 2015). This is

9 because high levels of power asymmetry leads to more adversarial relationships, as the more

10 powerful partner will tend to be more assertive in the business relationship (Tretyak and

11 Radaev, 2013). Additionally, a lack of understanding of relative power positions of chain

12 member may lead the supply chain members to build and use wrong strategies towards its

13 business partners. Besides showing the differences and similarities between the upstream and

14 downstream, our results also highlight the importance of business relationships to

15 agribusiness SMEs performance (Adams et al., 2012).

\section{Conclusions}

Results of this study give justification to the use of triad in studying supply chain relationships. Pooled sample results could not reveal the underlying differences in perception amongst supply chain members; which were clearly brought out when multi-group analysis was conducted. Consequently, a triadic analysis exposes the underlying dimensions of a supply chain better than a dyadic or firm level analysis.

By collecting and analyzing data at the supply chain level, this paper advances the empirical understanding of supply chain relationships. Theoretically, the results of this paper 
1 dyad is heavily influenced by the network in which it operates. This research also advances

2 the resource dependence theory, and builds on previous work by testing the role of power in 3 supply chain performance in an agribusiness SMEs context that has received limited attention 4 in literature. It further contributes to theory by empirically testing the model in a developing 5 country in Africa.

\section{Managerial implications}

8 Several implications can be drawn from this research. First, managers of agribusiness SMEs 9 should be aware of their power positions and use appropriate influences based on power positions in a supply chain. Since coercive and non-coercive power have contrasting effects on SCP, it is important that both power source and power target recognize the presence of power and reconcile their supply chain strategy to take into account power influences. For managers, this implies that being open about their power positions with supply chain members can help to improve on the performance of each member as well as the performance of the whole supply chain.

Secondly, SMEs in agribusiness would greatly benefit from trust and relation benefits, this implies that SMEs managers can enhance their positional advantage through realizing a better performance in the supply chain. Building a mutually beneficial relationship is critical, however, that requires a some level of commitment and understanding from all stakeholders. This can be attained by viewing the relationship as an investment wherein a supplier or a customer should be viewed as an extension of the SMEs. It is up to the focal firms to convey this approach to their suppliers and customers.

Thirdly, use of rewards and incentives (non-coercive power) is a strong gesture from a member that they value that relationship. Hence, supply chain members may need to consider providing incentives, such as awards, bonuses or performance incentives to their supply chain 
1 partners. Using incentives make partners feel appreciated and can result into a positive view

2 of the relationship. However, both researchers and managers in agribusiness SMEs should be

3 cautious of the recommendation that use of non-coercive power have a positive effect on the

4 quality. Finally, SMEs in the agribusiness sector need to limit the use of coercive power by

5 investing in the relational variables in order to improve efficiency, chain balance and

6 responsiveness.

\section{$7 \quad$ Limitations and future research}

8 Some limitations of this study are worth mentioning. Firstly, the study only focused on one

9 commodity chain in one country, which can limit the applicability of our findings. Future

10 studies could assess power perceptions across different commodity chains and countries to

11 understand if there are differences in perceptions. The second limitation arises from the use of

12 the matched triad approach of data collection. While ideal for studying a triad, this approach

13 is difficult to operationalize in the field especially where there is no established database for

14 SMEs. Future studies could replicate similar methodologies where businesses are more 15 formalized. 


\section{REFERENCES}

Adams, J. H., Khoja, F. M. and Kauffman, R. (2012) 'An empirical study of buyer-supplier relationships within small business organizations', Journal of Small Business Management, 50(1), pp. 20-40.

Ahmed, M. (2012) 'Analysis of incentives and disincentives for maize in Uganda. Technical notes Series'. Rome: FAO.

Anderson, E. and Weitz, B. (1992) 'The use of pledges to build and sustain commitment in distribution channels', Journal of marketing research, pp. 18-34.

Anderson, J. C. and Gerbing, D. W. (1988) 'Structural equation modeling in practice: A review and recommended two-step approach', Psychological bulletin, 103(3), p. 411.

Aramyan, L. H., Lansink, A. G. O., Van Der Vorst, J. G. and Van Kooten, O. (2007) 'Performance measurement in agri-food supply chains: a case study', Supply Chain Management: An International Journal, 12(4), pp. 304-315.

Arzu Akyuz, G. and Erman Erkan, T. (2010) 'Supply chain performance measurement: a literature review', International Journal of Production Research, 48(17), pp. 5137-5155.

Bastl, M., Johnson, M. and Choi, T. Y. (2013) 'Who's seeking whom? Coalition behavior of a weaker player in buyer-supplier relationships', Journal of Supply Chain Management, 49(1), pp. 8-28.

Belaya, V., Gagalyuk, T. and Hanf, J. (2009) 'Measuring asymmetrical power distribution in supply chain networks: what is the appropriate method?', Journal of Relationship Marketing, 8(2), pp. 165-193.

Belaya, V. and Hanf, J. H. (2011) 51st Annual Conference of German Association of Agricultural Economists (GEWISOLA), Halle. Retrieved December.

Besser, T. L. and Miller, N. J. (2010) 'The Significance of Customer Base in the New Economy: Satisfaction and Perceptions of Success among Small Suppliers and Small Nonsuppliers 1', Journal of Small Business Management, 48(1), pp. 1-15.

Boyer, K. K. and Swink, M. L. (2008) 'Empirical elephants-why multiple methods are essential to quality research in operations and supply chain management', Journal of Operations Management, 26(3), pp. 338-344.

Brown, J. R., Lusch, R. F. and Nicholson, C. Y. (1995) 'Power and relationship commitment: their impact on marketing channel member performance', Journal of Retailing, 71(4), pp. 363 392.

Brown, J. R., Lusch, R. F. and Nicholson, C. Y. (1996) 'Power and relationship commitment: their impact on marketing channel member performance', Journal of retailing, 71(4), pp. 363392.

Cai, S., Goh, M., de Souza, R. and Li, G. (2013) 'Knowledge sharing in collaborative supply chains: Twin effects of trust and power', International Journal of Production Research, 51(7), pp. 2060-2076. 
Chen, I. J. and Paulraj, A. (2004) 'Towards a theory of supply chain management: the constructs and measurements', Journal of operations management, 22(2), pp. 119-150.

Chicksand, D. (2015) 'Partnerships: The role that power plays in shaping collaborative buyersupplier exchanges', Industrial marketing management, 48, pp. 121-139.

Choi, T. Y. and Wu, Z. (2009) 'Taking the leap from dyads to triads: Buyer-supplier relationships in supply networks', Journal of Purchasing and Supply Management, 15(4), pp. 263-266.

Corsten, D. and Kumar, N. (2005) 'Do suppliers benefit from collaborative relationships with large retailers? An empirical investigation of efficient consumer response adoption', Journal of Marketing, pp. 80-94.

Crook, T. R. and Combs, J. G. (2007) 'Sources and consequences of bargaining power in supply chains', Journal of Operations Management, 25(2), pp. 546-555.

Cuevas, J. M., Julkunen, S. and Gabrielsson, M. (2015) 'Power symmetry and the development of trust in interdependent relationships: The mediating role of goal congruence', Industrial Marketing Management, 48, pp. 149-159.

Dalipagic, I. E., Gabriel (2014) 'Agricultural Value chain analysis in northern Uganda: maize, rice, groundnuts, sunflower and sesame'. (Accessed: 27/07/2016).

French, J. R., Raven, B. and Cartwright, D. (1959) 'The bases of social power', Classics of organization theory, pp. 311-320.

Fynes, B., de Burca, S. and Voss, C. (2005) 'Supply chain relationship quality, the competitive environment and performance', International Journal of Production Research, 43(16), pp. 3303-3320.

Gagalyuk, T., Hanf, J. and Hingley, M. (2013) 'Firm and whole chain success: network management in the Ukrainian food industry', Journal on Chain and Network Science, 13(1), pp. 47-70.

Gelinas, R. and Bigras, Y. (2004) 'The characteristics and features of SMEs: favorable or unfavorable to logistics integration?', Journal of Small Business Management, 42(3), pp. 263278.

Gellynck, X. and Molnár, A. (2009) 'Chain governance structures: the European traditional food sector', British Food Journal, 111(8), pp. 762-775.

Geyskens, I., Steenkamp, J.-B. E. and Kumar, N. (1999) 'A meta-analysis of satisfaction in marketing channel relationships', Journal of marketing Research, pp. 223-238.

Gunasekaran, A., Patel, C. and Tirtiroglu, E. (2001) 'Performance measures and metrics in a supply chain environment', International journal of operations \& production Management, 21(1/2), pp. 71-87.

He, Q., Ghobadian, A. and Gallear, D. (2013) 'Knowledge acquisition in supply chain partnerships: The role of power', International Journal of Production Economics, 141(2), pp. 605-618. 
Hingley, M., Angell, R. and Lindgreen, A. (2015) 'The current situation and future conceptualization of power in industrial markets', Industrial Marketing Management, 48, pp. 226-230.

Hingley, M. K. (2005) 'Power imbalance in UK agri-food supply channels: Learning to live with the supermarkets?', Journal of Marketing Management, 21(1-2), pp. 63-88.

Hu, L. t. and Bentler, P. M. (1999) 'Cutoff criteria for fit indexes in covariance structure analysis: Conventional criteria versus new alternatives', Structural equation modeling: a multidisciplinary journal, 6(1), pp. 1-55.

Janssens, W., Wijnen, K., De Pelsmacker, P. and Van Kenhove, P. (2008) Marketing research with SPSS. Pearson.

Jones, S. L., Fawcett, S. E., Wallin, C., Fawcett, A. M. and Brewer, B. L. (2014) 'Can small firms gain relational advantage? Exploring strategic choice and trustworthiness signals in supply chain relationships', International Journal of Production Research, 52(18), pp. 54515466.

Jonsson, P. and Zineldin, M. (2003) 'Achieving high satisfaction in supplier-dealer working relationships', Supply Chain Management: An International Journal, 8(3), pp. 224-240.

Kühne, B., Gellynck, X. and Weaver, R. D. (2013) 'The influence of relationship quality on the innovation capacity in traditional food chains', Supply Chain Management: An International Journal, 18(1), pp. 52-65.

Kühne, B., Gellynck, X. and Weaver, R. D. (2015) 'Enhancing Innovation Capacity Through Vertical, Horizontal, and Third-Party Networks for Traditional Foods', Agribusiness, 31(3), pp. 294-313.

Lackes, R., Schlüter, P. and Siepermann, M. (2015) 'The impact of contract parameters on the supply chain performance under different power constellations', International Journal of Production Research, pp. 1-14.

Lacoste, S. and Blois, K. (2015) 'Suppliers' power relationships with industrial key customers', Journal of Business \& Industrial Marketing, 30(5), pp. 562-571.

Li, B., Zhou, Y. and Wang, X. (2013) 'Equilibrium analysis of distribution channel structures under power imbalance and asymmetric information', International Journal of Production Research, 51(9), pp. 2698-2714.

Liu, H., Ke, W., Wei, K. K. and Hua, Z. (2015) 'Influence of power and trust on the intention to adopt electronic supply chain management in China', International Journal of Production Research, 53(1), pp. 70-87.

Maloni, M. and Benton, W. (2000) 'Power influences in the supply chain', Journal of Business Logistics, 21(1), pp. 49-74.

Matanda, M. J., Ndubisi, N. O. and Jie, F. (2016) 'Effects of Relational Capabilities and Power Asymmetry on Innovativeness and Flexibility of Sub $\square$ Sahara Africa Small Exporting Firms', Journal of Small Business Management, 54(1), pp. 118-138. 
Medlin, C. J. (2006) 'Self and collective interest in business relationships', Journal of Business Research, 59(7), pp. 858-865.

Mentzer, J. T., DeWitt, W., Keebler, J. S., Min, S., Nix, N. W., Smith, C. D. and Zacharia, Z. G. (2001) 'Defining supply chain management', Journal of Business logistics, 22(2), pp. 1-25.

MFPED (2016) Background to the Budget Kampala: Government of Uganda. [Online]. Available at: http://www.finance.go.ug/index.php/national-budget/background-to-the-budgetfor-financial-years.html (Accessed: 27/07/2016).

Minna Rollins, D. and Schreiner, A. (2015) 'Triadic analysis of business relationship's ending: a case study of a dyad and a third actor', Journal of Business \& Industrial Marketing, 30(8), pp. 891-905.

Molnár, A., Gellynck, X. and Weaver, R. D. (2010) 'Chain member perception of chain performance: the role of relationship quality', Journal on Chain and Network Science, 10(1), pp. 27-49.

Murthy, V. and Paul, B. (2016) 'Nature of Buyer-Supplier Relationship: Small Businesses in a Small City', Journal of Small Business Management.

Narasimhan, R. and Jayaram, J. (1998) 'Causal linkages in supply chain management: an exploratory study of North American manufacturing firms', Decision Sciences, 29(3), pp. 579605.

Neely, A., Gregory, M. and Platts, K. (1995) 'Performance measurement system design: a literature review and research agenda', International journal of operations \& production management, 15(4), pp. 80-116.

Nyaga, G. N., Lynch, D. F., Marshall, D. and Ambrose, E. (2013) 'Power asymmetry, adaptation and collaboration in dyadic relationships involving a powerful partner', Journal of Supply Chain Management, 49(3), pp. 42-65.

Nyaga, G. N., Whipple, J. M. and Lynch, D. F. (2010) 'Examining supply chain relationships: do buyer and supplier perspectives on collaborative relationships differ?', Journal of Operations Management, 28(2), pp. 101-114.

Odongo, W., Dora, M., Molnar, A., Ongeng, D. and Gellynck, X. (2016) 'Performance perceptions among food supply chain members: a triadic assessment of the influence of supply chain relationship quality on supply chain performance', British Food Journal, 118(7).

Park, D. and Krishnan, H. A. (2001) 'Supplier Selection Practices among Small Firms in the United States: Testing Three Models', Journal of Small Business Management, 39(3), pp. 259271.

Petrick, I., Maitland, C. and Pogrebnyakov, N. (2016) 'Unpacking Coordination Benefits in Supply Networks: Findings from Manufacturing SMEs', Journal of Small Business Management, 54(2), pp. 582-597.

Pfeffer, J. and Salancik, G. R. (1978) 'The external control of organizations: A resource dependence approach', NY: Harper and Row Publishers. 
Pulles, N. J., Veldman, J., Schiele, H. and Sierksma, H. (2014) 'Pressure or pamper? The effects of power and trust dimensions on supplier resource allocation', Journal of supply chain management, 50(3), pp. 16-36.

Rindt, J. and Mouzas, S. (2015) 'Exercising power in asymmetric relationships: the use of private rules', Industrial Marketing Management, 48, pp. 202-213.

Rungtusanatham, M., Choi, T. Y., Hollingworth, D. G., Wu, Z. and Forza, C. (2003) 'Survey research in operations management: historical analyses', Journal of Operations Management, 21(4), pp. 475-488.

Sakano, T. and Johnson, J. L. (1993) 'The exercise of interfirm power and its repercussions in US-Japanese channel relationships', Journal of marketing: A quarterly publication of the american marketing association, 57(2), pp. 1-10.

Sanfiel $\square$ Fumero, M. A., Ramos $\square$ Dominguez, Á. M. and Oreja $\square$ Rodríguez, J. R. (2012) 'The configuration of power in vertical relationships in the food supply chain in the Canary Islands', British Food Journal, 114(8), pp. 1128-1156.

Sheu, J.-B. (2015) 'Power shifts and relationship quality improvement of producer-retailer green channel dyads under government intervention', Industrial Marketing Management, 50, pp. 97-116.

Skinner, S. J., Gassenheimer, J. B. and Kelley, S. W. (1992) 'Cooperation in supplier-dealer relations', Journal of Retailing, 68(2), p. 174.

Sukwadi, R., Wee, H.-M. and Yang, C.-C. (2013) 'Supply Chain Performance Based on the Lean-Agile Operations and Supplier-Firm Partnership: An Empirical Study on the Garment Industry in Indonesia', Journal of Small Business Management, 51(2), pp. 297-311.

Terpend, R. and Ashenbaum, B. (2012) 'The intersection of power, trust and supplier network size: Implications for supplier performance', Journal of Supply Chain Management, 48(3), pp. 52-77.

Thomas, R. W., Fugate, B. S. and Koukova, N. T. (2011) 'Coping with time pressure and knowledge sharing in buyer-supplier relationships', Journal of Supply Chain Management, 47(3), pp. 22-42.

Touboulic, A., Chicksand, D. and Walker, H. (2014) 'Managing Imbalanced Supply Chain Relationships for Sustainability: A Power Perspective', Decision Sciences, 45(4), pp. 577-619.

Tretyak, O. and Radaev, V. (2013) 'Market power and relational conflicts in Russian retailing', Journal of Business \& Industrial Marketing, 28(3), pp. 167-177.

Wang, Q., Kayande, U. and Jap, S. (2010) 'The seeds of dissolution: discrepancy and incoherence in buyer-supplier exchange', Marketing Science, 29(6), pp. 1109-1124.

Whipple, J. M., Lynch, D. F. and Nyaga, G. N. (2010) 'A buyer's perspective on collaborative versus transactional relationships', Industrial Marketing Management, 39(3), pp. 507-518. 
Wu, Z., Choi, T. Y. and Rungtusanatham, M. J. (2010) 'Supplier-supplier relationships in buyer-supplier-supplier triads: Implications for supplier performance', Journal of Operations Management, 28(2), pp. 115-123.

Wuyts, S., Stremersch, S., Van den Bulte, C. and Franses, P. H. (2004) 'Vertical marketing systems for complex products: A triadic perspective', Journal of Marketing Research, pp. 479-487.

Wynstra, F., Spring, M. and Schoenherr, T. (2015) 'Service triads: A research agenda for buyer-supplier-customer triads in business services', Journal of Operations Management, 35(0), pp. 1-20.

Zhao, X., Huo, B., Flynn, B. B. and Yeung, J. H. Y. (2008) 'The impact of power and relationship commitment on the integration between manufacturers and customers in a supply chain', Journal of Operations Management, 26(3), pp. 368-388. 

8 10

21

23

24

25

27

28

32

33

34

35

36

39

40 
List of Table

Table 1: Profile of the sample (\%)

\begin{tabular}{|c|c|c|c|}
\hline Categorization & Supplier & Focal firm & Customer \\
\hline \multicolumn{4}{|l|}{ Business age } \\
\hline$\leq 5$ years & 10 & 12 & 10 \\
\hline $6-10$ years & 22 & 24 & 32 \\
\hline $11-20$ years & 62 & 50 & 46 \\
\hline$>20$ years & 6 & 14 & 12 \\
\hline \multicolumn{4}{|l|}{ Business size* } \\
\hline Micro & 32 & 16 & 22 \\
\hline Small & 68 & 78 & 77 \\
\hline Medium & - & 6 & 4 \\
\hline \multicolumn{4}{|l|}{ Product type } \\
\hline Flour & 14 & 82 & 82 \\
\hline Feeds & 50 & 4 & 2 \\
\hline Seeds & - & 14 & 12 \\
\hline Grains & 36 & - & 4 \\
\hline
\end{tabular}

Table 2: Exploratory factor analysis for SCP and power

\begin{tabular}{|c|c|c|c|}
\hline Construct & $\begin{array}{l}\text { Factor } \\
\text { loading }\end{array}$ & $\begin{array}{l}\text { Eigen } \\
\text { values }\end{array}$ & $\begin{array}{l}\text { Cronbach' } \\
\text { s alpha }\end{array}$ \\
\hline Supply chain performance & & & \\
\hline Efficiency $(E F F)$ & & 1.79 & 0.58 \\
\hline $\begin{array}{l}\text { Doing business with this XX helps my company to lower transport costs } \\
\text { significantly }\end{array}$ & 0.81 & & \\
\hline $\begin{array}{l}\text { Doing business with this XX helps my company to maintain acceptable } \\
\text { profitability }\end{array}$ & 0.49 & & \\
\hline $\begin{array}{l}\text { Doing business with this XX helps our company to significantly reduce } \\
\text { transaction costs }\end{array}$ & 0.76 & & \\
\hline Quality $(Q U A)$ & & 1.58 & 0.52 \\
\hline $\begin{array}{l}\text { Doing business with this XX contributes to reducing customer/consumer } \\
\text { complaints }\end{array}$ & 0.53 & & \\
\hline
\end{tabular}


Doing business with our XX helps my company to manage product safety $\quad 0.75$

Doing business with our XX helps my company to produce more attractive $\quad 0.72$ products

Responsiveness(RES)

Doing business with this XX helps my company to reduce lead time (time 0.68 from sending/getting the request till reply)

Doing business with this XX enable our company to deliver products on time $\quad 0.78$ Supply chain balance (BAL)

Doing business with this XX contributes to a more balanced distribution of 0.76 risks and benefits along the chain

Doing business with this XX helps my company to better understand other 0.70 chain members' interests

$K M O=0.68 ;$ Bartlets tests of sphericity: $X^{2}=219.11 ; p=0.000$

\section{Power}

Coercive power $(C P)$

We cannot be sure that this XX will not retaliate on our company (e.g. terminate contract, lower prices) when we do not accept their business proposal

We cannot be sure that this XX will not neglect our interests (terminate the contract without any notice) even if we fully meet the conditions detailed in the contract with them Non-coercive power (NCP)

Our company receives benefits from this XX when we regularly meet their 0.73 $2.07 \quad 0.97$ requirements (e.g. financial support, market information)

This XX rewards our company without requiring specific behaviour in return $\quad 0.92$ (e.g. financial support, better prices)

$K M O=0.56$; Bartlets tests of sphericity: $X^{2}=118.57 ; p=0.000$

Note: in the interview process, XX would be replaced with Supplier, customer and Focal firm to represent the FS, F-C; and C-Fand S-F context respectively.

Table 3: Standardized path estimation for sub-group specific estimates

\begin{tabular}{lllllll}
\hline \multicolumn{2}{c}{ Paths and perspectives } & \multicolumn{5}{c}{ Estimates } \\
\cline { 4 - 7 } & & & $S-F$ & $F-S$ & $F-C$ & $C-F$ \\
\hline Coercive power & $\rightarrow$ & Efficiency & $-0.61^{* * *}$ & 0.43 & 0.25 & -0.20 \\
Coercive power & $\rightarrow$ & Quality & 0.02 & -0.58 & -0.20 & $-0.73^{* * *}$ \\
Coercive power & $\rightarrow$ & Responsiveness & -0.16 & $0.22^{* * *}$ & 0.00 & -0.04 \\
Coercive Power & $\rightarrow$ & Chain balance & $-0.07^{*}$ & 0.23 & -0.36 & $-0.55^{* *}$ \\
Non-coercive power & $\rightarrow$ & Efficiency & 0.22 & 0.67 & 0.47 & 0.06 \\
Non-coercive power & $\rightarrow$ & Quality & -0.01 & -0.24 & 0.04 & $-0.45^{*}$ \\
Non-coercive power & $\rightarrow$ & Responsiveness & 0.20 & $0.16^{*}$ & 0.73 & 0.16 \\
Non-coercive power & $\rightarrow$ & Chain balance & -0.01 & $1.16^{*}$ & 0.14 & -0.11
\end{tabular}

Note: $1 . * * *, * * *$ indicates significance at $0.05,0.01$ and 0.00 respectively

2. $F=$ focal firm; $S=$ supplier; $C=$ customer

3. $S$-F=suppliers perception about the focal firm; $F-S=$ focal firms perception about supplier; $F$ -

$C=$ focal firms perception about customer; and $C-F=$ customers perception about focal firm 


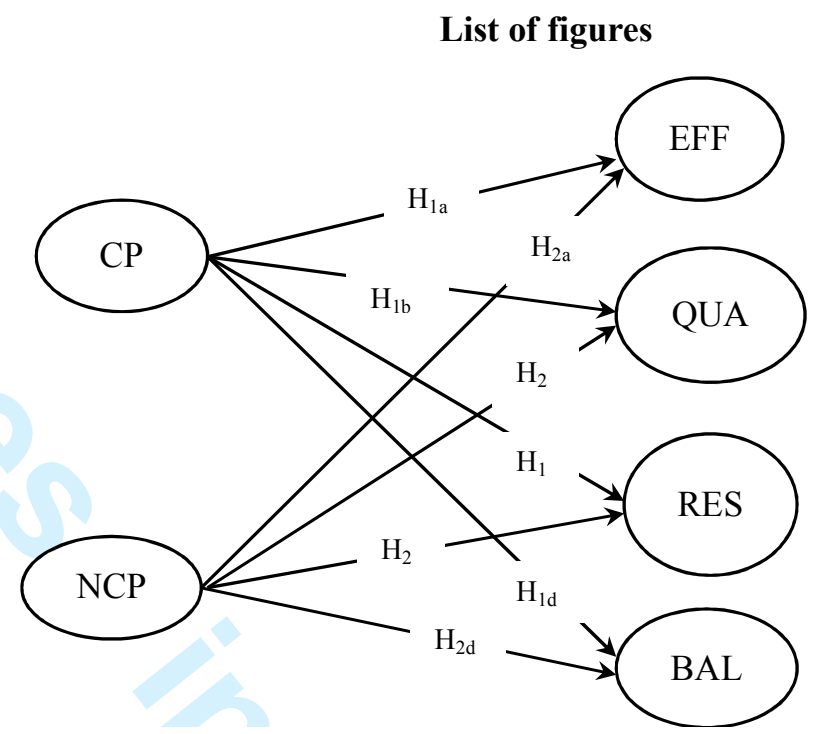

Figure 3: Conceptual framework and hypotheses

$\mathrm{CP}=$ coercive power; $\mathrm{NCP}=$ non-coercive power; $\mathrm{EFF}=$ efficiency; $\mathrm{QUA}=$ quality; $\mathrm{RES}=$ responsiveness; $\mathrm{BAL}=$ chain balance

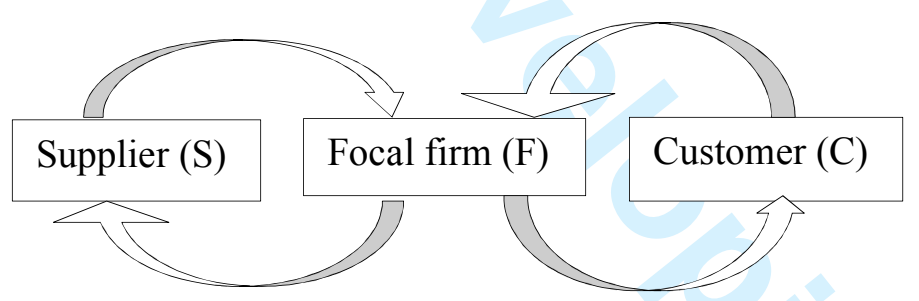

Figure 2: Relationship directions considered in data collection and analysis

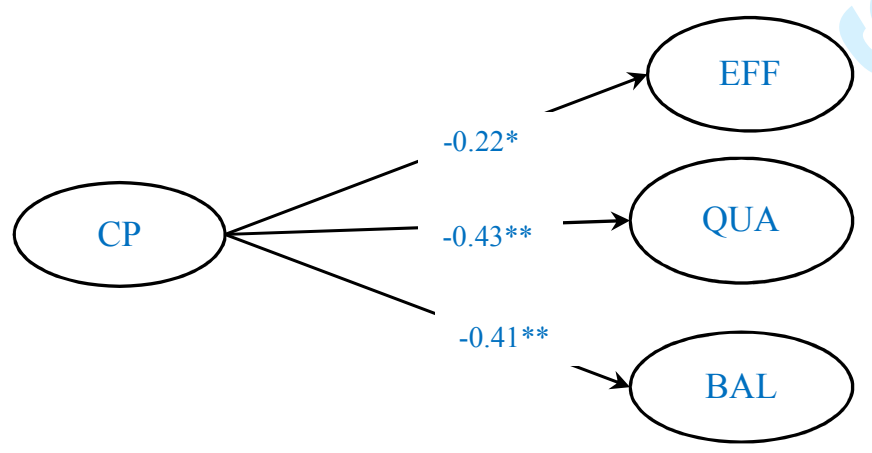

Figure 1: Significant paths for the pooled sample $\mathrm{CP}=$ coercive power; $\mathrm{EFF}=$ efficiency; $\mathrm{QUA}=$ quality; $\mathrm{BAL}=$ chain balance 